\title{
Oral Treatment with Extract of Agaricus blazei Murill Enhanced Th1 Response through Intestinal Epithelial Cells and Suppressed OVA-Sensitized Allergy in Mice
}

\author{
Go Bouike, ${ }^{1}$ Yosuke Nishitani, ${ }^{2}$ Hideyuki Shiomi, ${ }^{3}$ Masaru Yoshida, ${ }^{3}$ Takeshi Azuma, ${ }^{3}$ \\ Takashi Hashimoto, ${ }^{1}$ Kazuki Kanazawa, ${ }^{1}$ and Masashi Mizuno ${ }^{1}$ \\ ${ }^{1}$ Department of Agrobioscience, Graduate School of Agricultural Science, Kobe University, 1-1, Rokkodai-cho, Nada-ku, \\ Kobe, 657-8501, Japan \\ ${ }^{2}$ Health Bioscience Team, Organization of Advanced Science and Technology, Kobe University, Kobe 657-8501, Japan \\ ${ }^{3}$ Department of Internal Medicine, Graduate school of Medicine, Kobe University, Kobe 650-0017, Japan
}

Correspondence should be addressed to Masashi Mizuno, mizuno@kobe-u.ac.jp

Received 7 June 2010; Accepted 28 August 2010

Copyright (๑) 2011 Go Bouike et al. This is an open access article distributed under the Creative Commons Attribution License, which permits unrestricted use, distribution, and reproduction in any medium, provided the original work is properly cited.

To clarify the mechanism of the antiallergic activity of Agaricus blazei Murill extract (ABME), the present paper used an in vivo allergy model and an in vitro intestinal gut model. During OVA sensitization, the serum IgE levels decreased significantly in ABME group. Interleukin (IL)-4 and -5 produced from OVA-restimulated splenocytes was significantly decreased, and anti-CD3e/CD28 antibody treatment also reduced IL-10, -4 , and -5 production and increased IFN- $\gamma$ production in ABME group. These results suggest that oral administration of ABME improves Th1/Th2 balance. Moreover, a coculture system constructed of Caco- 2 cells and splenocytes from OT-II mice or RAW 264.7 cells indicated that the significant increases in IFN- $\gamma$ production by ABME treatment. Therefore, it was concluded that the antiallergic activity of ABME was due to the activation of macrophages by epithelial cells and the promotion of the differentiation of naïve T cells into Th1 cells in the immune.

\section{Introduction}

There are four types of hypersensitivity disease, and the incidence of type I allergy has been increasing worldwide $[1,2]$. Type I allergy is characterized by a high level of immunoglobulin E (IgE) antibodies arising from hypersensitive reactions to allergens such as pollen or food. This incidence caused by environmental factors, exposure to large amounts of antigen, and genetics can affect all age groups at any time in life. In particular, there has been a marked increase in the prevalence of allergies in children and young adults [3].

Agaricus blazei Murill is one of the most intensively studied medicinal mushrooms [4-6] among the mushrooms used to treat many diseases [7-11]. It was reported that the extract of A. blazei Murill had a potent antitumor activity in mice, and its antitumor activity was postulated to be exerted through mediation of the immune system of the host by $\beta$ - $(1,6)$ - and $\beta$ - $(1,3)$-glucan $[5,6,12-15]$. From these reports, these functions of $A$. blazei Murill have been shown to indirectly affect immune systems.
The mechanism of the pathogenesis of type I allergy is initiated by phagocytosis of allergens by antigen-presenting cells (APC), which represent a part of the antigen on MHC class II molecules to T cell receptors (TCR) on naïve T cells. On the basis of their cytokine production profiles, $\mathrm{CD} 4^{+} \mathrm{T}$ cells can be subdivided into two distinct populations, the $\mathrm{T}$ helper type 1 (Th1) and T helper type 2 (Th2) cells [16]. Th2 cells predominantly produce interleukin (IL)- 4 and IL-5 [17]. In contrast, Th1 cells mainly secrete cytokines such as IL-2 and interferon (IFN) $-\gamma[18,19]$. The balance between Th1- and Th2-dominant immunity (Th1/Th2 balance) is thought to be important for the development of various diseases.

The gut forms a barrier between the internal environment and the outside. Of the various cells that exist in the gut, intestinal epithelial cells (IEC), and macrophages are some of the most important in gut immune systems. The IEC physically prevent the invasion of numerous xenobiotics such as microorganisms and their metabolites from the intestine [20], and, macrophages, which are major APC, play a key role in antigen-specific immunological responses. It 
has been suggested that the activation of APC is a crucial point in skewing of the balance between Th1 and Th2 immune responses [21]. Intestinal macrophages are major cells in the human mononuclear phagocytic system and are preferentially localized in the subepithelial region [22]. Some studies in gut immune systems have reported that APC are able to select Th1 or Th2 differentiation $[23,24]$. In order to investigate the antiallergic effects induced by oral administration of functional foods, it is important to paper the effects of foods that are able to stimulate APC and antigen specific immunological responses through IEC.

Recently, many reports have shown that A. blazei Murill has beneficial effects in vivo $[12,25,26]$. However, little information is available on the mechanism of the antiallergic effects induced by oral administration of A. blazei Murill. The aim of this study was to clarify the mechanism of the antiallergic effects exhibited after oral administration of $A$. blazei Murill extracts (ABME) using an in vivo allergy model mouse and an in vitro intestinal gut model.

\section{Materials and Methods}

2.1. Reagents and Preparation of A. blazei Murill Extract. Dulbecco's Modified Eagle Medium (DMEM), actinomycin D, lipopolysaccharide (LPS) from E. coli O127, and murine recombinant tumor necrosis factor (TNF)- $\alpha$ were purchased from Wako Pure Chemical Industries (Osaka, Japan). Eagle's Minimum Essential Medium (MEM) was purchased from Nissui pharmaceutical (Tokyo, Japan). RPMI 1640 medium, MEM nonessential amino acids (NEAA), and trypsin were purchased from GIBCO BRL (Grand Island, NY, USA). $\mathrm{PiCl}$ was purchased from Tokyo Chemical Industries (Tokyo, Japan). Mouse anti-2,4,6-trinitrophenyl (TNP) monoclonal IgE was purchased from BD pharmingen (San Diego, USA). Ovalbumin (OVA) and $\mathrm{Al}(\mathrm{OH})_{3}$ adjuvant were purchased from Sigma (St. Luis, MO, USA). Antimouse CD3 $\varepsilon$ antibody and antimouse CD28 antibody were purchased from Biolegend (San Diego, USA). The other chemicals and reagents were ordinary commercial and guaranteed products. A. blazei Murill (Iwade strain 101) extract (ABME) which was composed of hot water extracts from mycelium and fruiting body, and alkaline extracts of fruting body was donated by the Iwade Mushroom Institute (Mie, Japan).

2.2. Mice. Female 3-week-old BALB/c mice were purchased from SLC (Shizuoka, Japan). The mice were housed in an airconditioned animal room at $23 \pm 2^{\circ} \mathrm{C}$ and acclimated for 7 days before the experiments. The mice were fed a laboratory diet (Nihon Nosan, Yokohama, Japan) and water ad libitum. OVA-specific TCR transgenic mice with a C57BL/6J background (OT-II) were purchased from the Jackson Laboratory (Bar Harbor, ME). OT-II mice were originally generated by Barnden et al. [27, 28]. The animal treatments in the present study followed established rules and guidelines approved for animal use and care at Kobe University (The Guidelines for the Care and Use of Experimental Animals of Rokkodai Campus, Kobe University).
2.3. IgE-Dependent PCA Reaction in BALB/c Mice. A passive cutaneous anaphylaxis (PCA) reaction was induced with $\mathrm{PiCl}$ to determine an approximate drinking concentration of ABME. ABME was suspended in sterilized distilled water at concentrations of $6.0,1.2,0.24$, and $0.048 \mathrm{mg} / \mathrm{ml}$. Female 5 -week-old $\mathrm{BALB} / \mathrm{c}$ mice were given the extract suspension in their drinking water for 4 days. Then, the mice were passively sensitized by injecting $2 \mu \mathrm{g} / 100 \mu \mathrm{l}$ of mouse antiTNP monoclonal IgE preparation intravenously into their tail veins. The PCA reaction was evoked by painting $10 \mu \mathrm{l}$ of $0.8 \% \mathrm{PiCl}$ acetone-olive oil $(1: 1)$ solution onto the surface of an earlobe. Ear thickness was measured before and $2 \mathrm{~h}$ after the PiCl challenge using a micrometer (Ozaki MFG Co., Ltd, Tokyo, Japan), and edema was calculated according to differences in ear thickness before and after $\mathrm{PiCl}$ challenge.

2.4. OVA Immunization Protocol in BALB/c Mice. Female 4week-old $\mathrm{BALB} / \mathrm{c}$ mice were given the ABME suspension in their drinking water for 32 days. First sensitization was achieved by intraperitoneally injecting $300 \mu \mathrm{l}$ PBS containing $10 \mu \mathrm{g}$ OVA mixed with $1 \mathrm{mg} \mathrm{Al}(\mathrm{OH})_{3}$ adjuvant. Subsequently, the mice were challenged using an intraperitoneal injection of $300 \mu \mathrm{l}$ PBS containing $10 \mu \mathrm{g}$ of OVA mixed with $0.5 \mathrm{mg} \mathrm{Al}(\mathrm{OH})_{3}$ adjuvant every 5 days for 4 weeks after the first OVA injection. Some mice were injected with $\mathrm{Al}(\mathrm{OH})_{3}$ adjuvant as a control.

2.5. Analysis of OVA-Specific and Antigen-Nonspecific Cytokine Responses in BALB/c Mice Splenocytes. Splenocytes were prepared from each mouse followed by Segawa et al. [29]. To determine OVA-specific cytokine production, the hemolyzed splenocytes $\left(5 \times 10^{6}\right.$ cells $\left./ \mathrm{ml}\right)$ were stimulated with $25 \mu \mathrm{g} / \mathrm{ml}$ OVA in a 96-well flat-bottom well microplate for $72 \mathrm{~h}$. After incubation, the culture supernatants were collected for the measurement of cytokines using a Cytometric bead array immunoassay kit (Beckman Coulter, Fullerton, CA, USA) according to manufacturer's protocol.

To determine antigen-nonspecific cytokine production by $\mathrm{T}$ cells, $5 \mu \mathrm{g} / \mathrm{ml}$ antimouse $\mathrm{CD} 3 \varepsilon$ antibody and $5 \mu \mathrm{g} / \mathrm{ml}$ antimouse CD28 antibody were used. The hemolyzed splenocytes in RPMI1640 medium from the OVA-sensitized mice were incubated in a glass dish (diameter: $9 \mathrm{~cm}$, Iwaki) to remove adherent cells. After $2 \mathrm{~h}$ incubation, nonadherent cells in the cultured medium were collected and resuspended at a concentration of $5 \times 10^{6}$ cells/ml in RPMI 1640 medium. These nonadherent splenocytes were seeded onto the 96well microplate $\left(5 \times 10^{5}\right.$ cells/well $)$ containing the antimouse CD $3 \varepsilon$ antibody and $5 \mu \mathrm{g} / \mathrm{ml}$ antimouse CD28 antibody. After incubation for $48 \mathrm{~h}$, the culture supernatants were collected for the measurement of cytokines using the same methods as used for the OVA-specific cytokines.

2.6. Blood Samples. Blood samples from each mouse were obtained from the tail vein every 5 days, and whole blood was collected from the postcaval vein on the day of sacrifice. To prepare serum samples, the blood samples were centrifuged at $10,000 \mathrm{rpm}$ for 10 minutes after incubation at room 


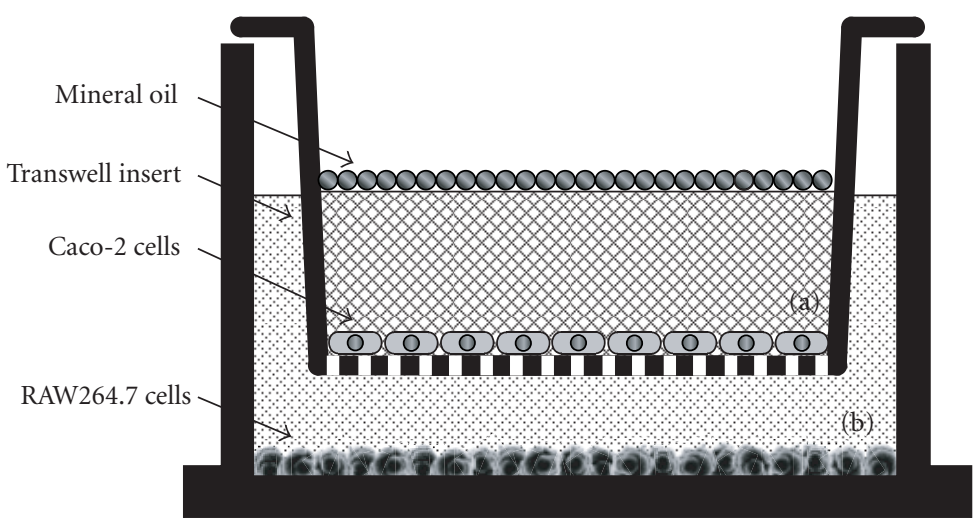

Figure 1: In vitro intestinal gut model constructed with Caco-2 cells in apical compartment (a) and RAW264.7 cells in basolateral compartment (b). Transwell inserts on which Caco-2 cells had been cultured were inserted into multiple plate wells containing RAW264.7 cells. Mineral oil ( $50 \mu \mathrm{l} /$ well) was added to the surface of the apical compartment (a) to mimic anaerobic conditions.

temperature for 30 minutes. Serum samples were stored at $-80^{\circ} \mathrm{C}$ until use.

2.7. Cell Culture. Cells of the human intestinal epithelial cell line Caco-2 were cultured in DMEM (high glucose), supplemented with $1 \%$ MEM-NEAA, $100 \mathrm{U} / \mathrm{ml}$ penicillin, $100 \mu \mathrm{g} / \mathrm{ml}$ streptomycin, and $10 \%$ heat-inactivated fetal bovine serum (FBS), and cells of the murine macrophage cell line RAW 264.7 were cultured in DMEM (glutamine, low glucose) supplemented with 10\% heat-inactivated FBS, $100 \mathrm{U} / \mathrm{ml}$ penicillin, and $100 \mu \mathrm{g} / \mathrm{ml}$ streptomycin. Cells of the murine fibrosarcoma cell line L929 were cultured in MEM supplemented with 10\% FBS, 2 mM L-glutamine, $100 \mathrm{U} / \mathrm{ml}$ penicillin, and $100 \mu \mathrm{g} / \mathrm{ml}$ streptomycin. All cell cultures were incubated in a humidified $5 \% \mathrm{CO}_{2}$ incubator at $37^{\circ} \mathrm{C}$.

2.8. Coculture System Constructed with Caco-2 Cells/OT-II Mice-Derived Splenocytes. To examine the effects of ABME on the OVA-specific response mediated via IEC, Caco2 cells and splenocytes from OT-II mice were cocultured using Transwell inserts. OT-II mice-derived splenocytes were prepared as described above. Caco- 2 cells were seeded at $4.5 \times$ $10^{5}$ cells/well in RPMI1640 onto transwell insert plates. The cell culture medium was changed every 3 days until the cells were fully differentiated. The splenocytes were suspended at a concentration of $4.5 \times 10^{5}$ cells/well in RPMI1640 $(500 \mu \mathrm{l})$ in a 24-well tissue culture plate and were incubated for $2 \mathrm{~h}$ in a $5 \% \mathrm{CO}_{2}$ incubator at $37^{\circ} \mathrm{C}$ to precipitate cells on the plate bottom. The transwell inserts on which the Caco-2 cells had been cultured were then added to the 24-well tissue culture plate. Two hundred microliters of ABME $(250 \mu \mathrm{g} / \mathrm{ml})$ were applied to the apical side for $3 \mathrm{~h}$. After incubation, the inserts were removed, and the splenocytes were restimulated with $10 \mu \mathrm{g} / \mathrm{ml}$ OVA for $72 \mathrm{~h}$. After incubation, the culture supernatants were collected for the measurement of TNF- $\alpha$ and IFN- $\gamma$.

2.9. Caco-2/RAW264.7 Cells Coculture System. RAW264.7 cells $\left(4.5 \times 10^{5}\right.$ cells $\left./ \mathrm{ml}\right)$ were plated at $500 \mu \mathrm{l} /$ well in a 24 well tissue culture plate containing DMEM and cultured for
$24 \mathrm{~h}$. The DMEM was removed from the 24-well plate, and transwell inserts containing differentiated Caco-2 cells were placed to the 24-well plates preloaded with RAW264.7 cells. Fresh RPMI 1640 media were used to replace the media in both the apical (a) and basolateral (b) compartments (Figure 1). Furthermore, mineral oil ( $50 \mu \mathrm{l} /$ well) was added to the surface of the apical compartment to mimic anaerobic conditions. After $24 \mathrm{~h}$ incubation, the mineral oil and culture media of the apical and basolateral compartments were changed for fresh oil and media, and then the cells were incubated. After additional incubation for $12 \mathrm{~h}$, the culture medium in the apical compartment was removed, and RPMI1640 medium containing ABME $(250 \mu \mathrm{g} / \mathrm{ml})$ or LPS $(25 \mu \mathrm{g} / \mathrm{ml})$ was applied for an additional $12 \mathrm{~h}$ incubation. The culture supernatants of the basolateral compartment were collected for TNF- $\alpha$ and NO measurement.

2.10. Cytokines and IgE Content Measurement. TNF- $\alpha$ content was quantified using a cytotoxicity assay involving L929 cells (an actinomycin D-treated murine fibroblast cell line) and murine rTNF- $\alpha$ as the standard as described by Takada et al. [30]. IFN- $\gamma$, IL-4, and total IgE contents were measured with ELISA kits (OptEIA set, BD Biosciences, San Diego, $\mathrm{CA}$ ) in accordance with the manufacturer's instructions. Nitrite as the end product of Nitric oxide (NO) was measured by using Griess reagent (1\% sulfanilamide/0.1\% N1-naphthylethylenediamine dihydrochloride/2.5\% $\mathrm{H}_{3} \mathrm{PO}_{4}$ ) followed by Green et al. [31].

2.11. Immunoprecipitation of ABME with Anti-FIII-2b Polyclonal Antibody. Anti-FIII-2-b polyclonal antibody was prepared as described by Mizuno et al. [32]. The antibody was incubated with ABME $(250 \mu \mathrm{g} / \mathrm{ml})$ or FIII-2-b $(250 \mu \mathrm{g} / \mathrm{ml})$ at $4^{\circ} \mathrm{C}$ for $2 \mathrm{~h}$, and then the reaction mixture was centrifuged at $7000 \mathrm{rpm}$ for 5 minutes. The supernatant was added to the apical side of the coculture system.

2.12. Statistical Analysis. Data are expressed as the mean $\pm \mathrm{SE}$. Statistical analysis was performed using the Student's $t$-test. Statistical significance was defined as $P<.05$. 


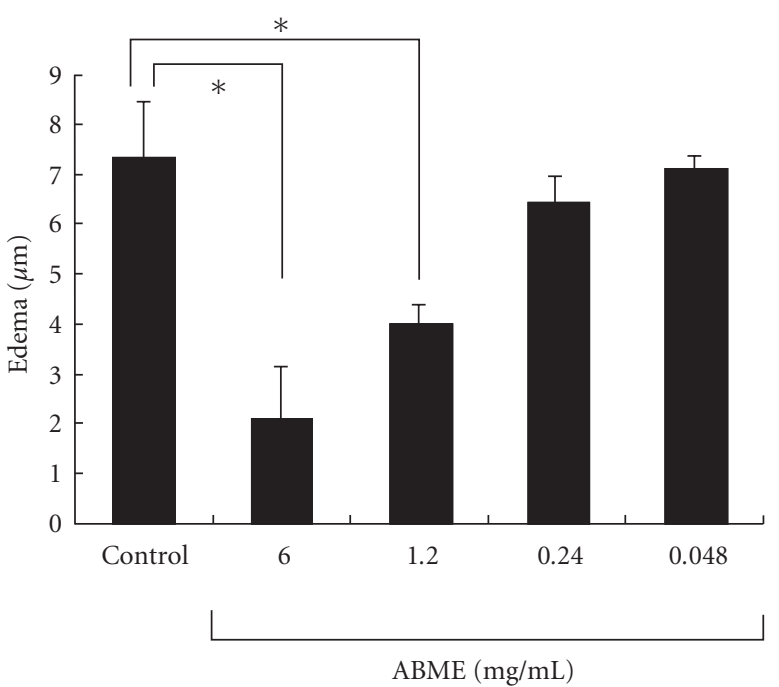

FIGURE 2: Effects of ABME on the passive cutaneous anaphylaxis reaction in the ears of $\mathrm{BALB} / \mathrm{c}$ mice. $\mathrm{BALB} / \mathrm{c}$ mice were given 0.048 , $0.24,1.2$, or $6.0 \mathrm{mg} / \mathrm{ml} \mathrm{ABME}$ in their drinking water, and passive cutaneous anaphylaxis (PCA) was induced as described in Materials and Methods. Edema was measured before and after PiCl challenge. Values represent the means \pm S.E. of 4 mice in each group. ${ }^{*} P<.05$, significantly different from the values of the control group.

\section{Results}

3.1. Suppression of the Anti-TNP IgE-Mediated PCA Reaction by Oral Administration of ABME. The PCA reaction was evoked by painting of $\mathrm{PiCl}$. Oral administration of ABME did not cause any significant difference in weight or drinking amount compared with the control group at any concentration throughout the experiment (data not shown). Furthermore, results demonstrated that the administration of ABME at concentrations of 1.2 and $6.0 \mathrm{mg} / \mathrm{ml}$ significantly inhibited edema compared with the control group in a dosedependent manner (Figure 2).

3.2. Downregulation of Serum Immunoglobulin E Levels by Oral Administration of $A B M E$ in $B A L B / c$ Mice. Antiallergic effects of $A B M E$ on allergen-specific responses were examined using BALB/c mice sensitized with OVA. ABME was administered to the mice at the same concentrations in the PCA reaction experiment. Oral administration of ABME did not cause significant changes in weight loss or drinking amount (data not shown). IgE levels increased rapidly after the second injection and then gradually increased until the forth injection in the control group (Figure 3). However, the IgE levels in the ABME-treated group were lower than those in the control group after the third injection, and thereafter they were almost the same. On day 14 of this treatment, the IgE levels in the mice administered 6.0 or $1.2 \mathrm{mg} / \mathrm{ml} \mathrm{ABME}$ had significantly decreased to $8.5 \pm 1.1$ and $10.1 \pm 0.5 \mu \mathrm{g} / \mathrm{ml}$, respectively, compared with the control mice $(14.1 \pm 0.6 \mu \mathrm{g} / \mathrm{ml})$. These results indicated that oral administration of ABME downregulated the IgE level in serum at concentrations above $1.2 \mathrm{mg} / \mathrm{ml}$.

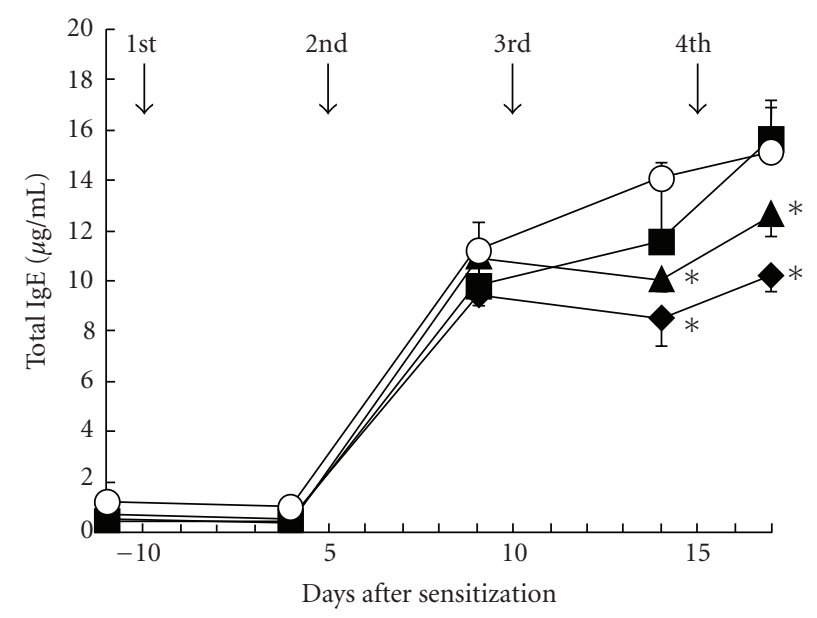

$$
\begin{array}{ll}
\text { Control } & \boldsymbol{\Delta} \text { ABME } 1.2 \mathrm{mg} / \mathrm{mL} \\
\text { ABME } 0.24 \mathrm{mg} / \mathrm{mL} & \boldsymbol{A B M E ~} 6 \mathrm{mg} / \mathrm{mL}
\end{array}
$$

Figure 3: Effect of ABME on OVA sensitization in BALB/c mice The arrows show the days corresponding to the injections of OVA. Serum was obtained from each mouse on the day before each OVA injection, and the level of total IgE was determined by ELISA. Values represent the means \pm S.E. of 5 mice in each group. ${ }^{*} P<.05$, significantly different from the values of the control group.

3.3. Inhibitory Effect of $A B M E$ on Immune Responses in Splenocytes from OVA-Sensitized BALB/c Mice. To examine OVA-specific cytokine responses in OVA-sensitized mice, their splenocytes were treated with OVA $(25 \mu \mathrm{g} / \mathrm{ml})$. The IL4 production in the 6.0 and $1.2 \mathrm{mg} / \mathrm{ml} \mathrm{ABME} \mathrm{groups} \mathrm{was}$ significantly decreased to $19.1 \pm 11.7$ and $15.1 \pm 14.0 \mathrm{pg} / \mathrm{ml}$ compared with the control group $(183.3 \pm 53.3 \mathrm{pg} / \mathrm{ml})$ (Figure 4(a)). Furthermore, the IL-5 production was significantly decreased to $50.4 \pm 27.5 \mathrm{pg} / \mathrm{ml}$ in the $6.0 \mathrm{mg} / \mathrm{ml}$ of ABME group compared with the control group (369.1 \pm $43.5 \mathrm{pg} / \mathrm{ml}$ ) (Figure 4(b)). However, IFN- $\gamma$ production, a typical Th1 cytokine, was lower than the detection limit in all groups. These results indicated that oral administration of ABME decreased Th2 response of splenocytes sensitized by OVA. To confirm this, we focused on the $\mathrm{T}$ cell antigen receptor signal transduction pathway.

When antigen presenting cells (APC) such as macrophages present an antigenic fragment, $\mathrm{T}$ cell activation is dependent on signals delivered through the $\mathrm{T}$ cell receptor (TCR)-CD3 complex and the major $\mathrm{T}$ cell costimulatory receptor CD28 on the $\mathrm{T}$ cell [33-35]. To examine Th1/Th2 cytokine responses mediated via these signaling pathways, spleen cells were treated simultaneously with anti-CD $3 \varepsilon$ - and anti-CD28 antibodies. IL-4, IL-5, and IL-10 production was suppressed by ABME administration in a dose-dependent manner and significantly decreased to $2.4 \pm 0.4 \mathrm{ng} / \mathrm{ml}$, $656.2 \pm 44.1 \mathrm{pg} / \mathrm{ml}$, and $670.0 \pm 70.5 \mathrm{pg} / \mathrm{ml}$, respectively, in $6.0 \mathrm{mg} / \mathrm{ml}$ the ABME group (Figures $5(\mathrm{a})-5(\mathrm{c})$ ). On the other hand, IFN- $\gamma$ production was significantly increased compared with the control group (Figure 5(d)). These results suggested that the Th1 response in the splenocytes was increased and the Th2 response was decreased depending 


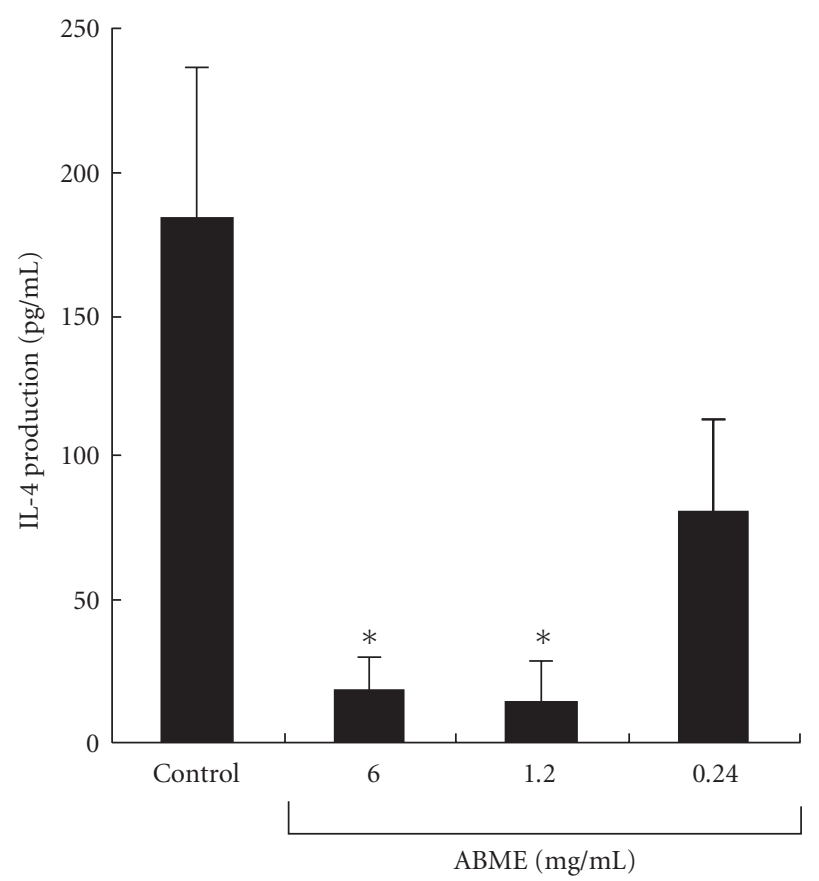

(a)

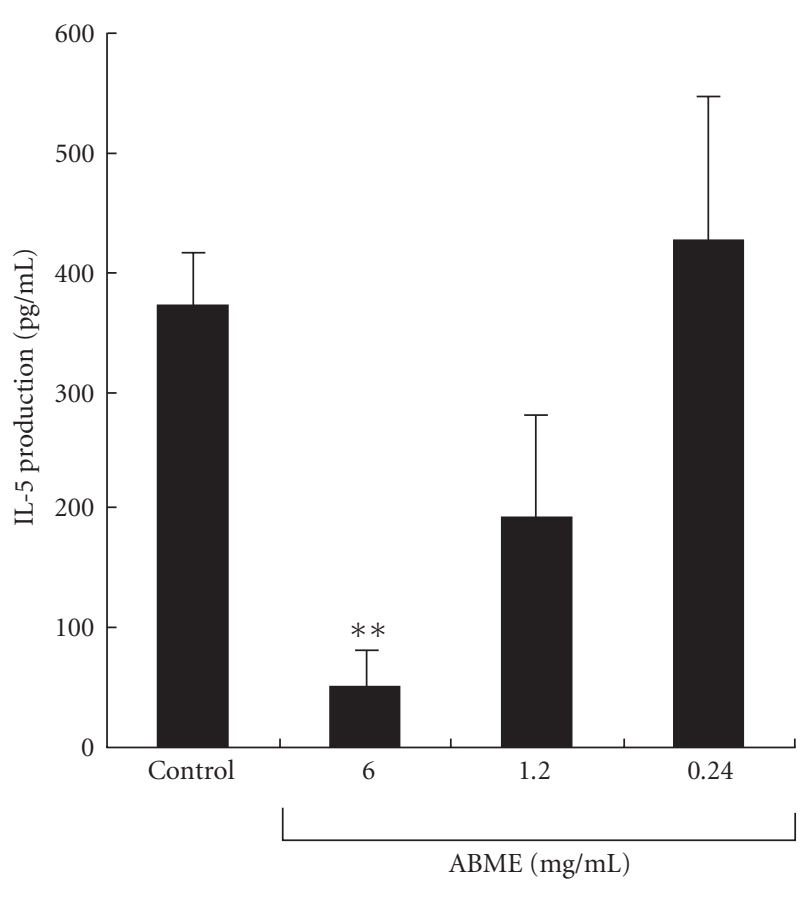

(b)

FIGURE 4: Effect of ABME on the production of the Th2 cytokines IL-4 and 5 from antigen-restimulated splenocytes in OVA-sensitized mice. Two days after the last OVA injection, the spleen cells isolated from each mouse were restimulated with $25 \mu \mathrm{g} / \mathrm{ml} \mathrm{OVA}$. After incubation at $37^{\circ} \mathrm{C}$ for $72 \mathrm{~h}$, the levels of IL-4 (a) and IL-5 (b) in the culture supernatants were determined using a cytometric bead array immunoassay. Values represent the means \pm S.E. of 5 mice in each group. ${ }^{*} P<.05,{ }^{* *} P<.01$, significantly different from the values of the control group.

on the concentration of ABME ingested when the $\mathrm{T}$ cell antigen receptor signal transduction pathway was activated.

\subsection{Effect of ABME on OVA Stimulated Splenocytes Prepared} from OT-II Mice via Caco-2 Cells in CoCulture System. As shown in Figure 5, oral administration of ABME dosedependently decreased the Th2 response and increased the Th1 response in the spleens of OVA-sensitized mice. In order to investigate how orally administered ABME affects immune cells in the gut, the effect of ABME on IFN- $\gamma$ production was measured in a coculture system constructed of Caco-2 cells and splenocytes prepared from OT-II mice. Since the $\mathrm{T}$ cells in splenocytes from OT-II mice highly express an OVA-specific T cell receptor (TCR), the Th1/Th2 cytokine balance can be examined by using OVA as a stimulator. As shown in Figure 6(a), treatment of Caco-2 cells with ABME prior to the stimulation of splenocytes with OVA significantly increased IFN- $\gamma$ production on the basolateral side compared with that observed without ABME stimulation. No significant change was recognized in the coculture system with and without ABME under nonstimulation with OVA. Similarly, ABME pretreatment enhanced TNF- $\alpha$ production through Caco-2 cells (Figure 6(b)). These results suggested that the lymphocytes that can produce TNF- $\alpha$ were activated by ABME pretreatment via Caco- 2 cells, and then, OVAspecific naïve $\mathrm{T}$ cells were differentiated into Th1 cells, which can produce INF- $\gamma$.
3.5. Effect of ABME on RAW264.7 Cells via Caco-2 Cells in the Coculture System. In the Caco-2/OT-II splenocytes coculture system, ABME induced TNF- $\alpha$ production from OVA restimulated splenocytes via Caco- 2 cells. TNF- $\alpha$ is one of the major cytokines secreted from APC such a macrophages and dendritic cells. Then, the effects of ABME on macrophages were examined using Caco-2/RAW264.7 coculture system. ABME $(250 \mu \mathrm{g} / \mathrm{ml})$ treatment for $12 \mathrm{~h}$ to the apical compartment significantly upregulated the TNF- $\alpha$ production from RAW264.7 cells (Figure 7(a)). However, ABME did not induced TNF- $\alpha$ production from RAW264.7 cells directly (Figure 7(b)). NO production did not induced by ABME treatment (Figure 7(c)), although the direct treatment of ABME to RAW 264.7 did (Figure 7(d)). These results indicate that ABME cannot induce TNF- $\alpha$ production from RAW264.7 cells without interacting with Caco-2 cells, and Caco-2 cells can cancel NO production from RAW 264.7 cells.

To identify which compounds in ABME enhance TNF$\alpha$ production from RAW264.7 cells, immunoprecipitation using an anti-FIII-2-b antibody was applied. This antibody recognizes the FIII-2-b fraction which was purified as the most active fraction in alkaline-soluble fractions of $A$. blazei Murill [12]. As shown in Figure 8, the anti-FIII-2-b antibody significantly suppressed TNF- $\alpha$ production from RAW264.7 to a control levels in a coculture system in which Caco- 2 cells were treated FIII-2-b or ABME. This result indicated that the active compound contained in ABME is FIII-2-b. 


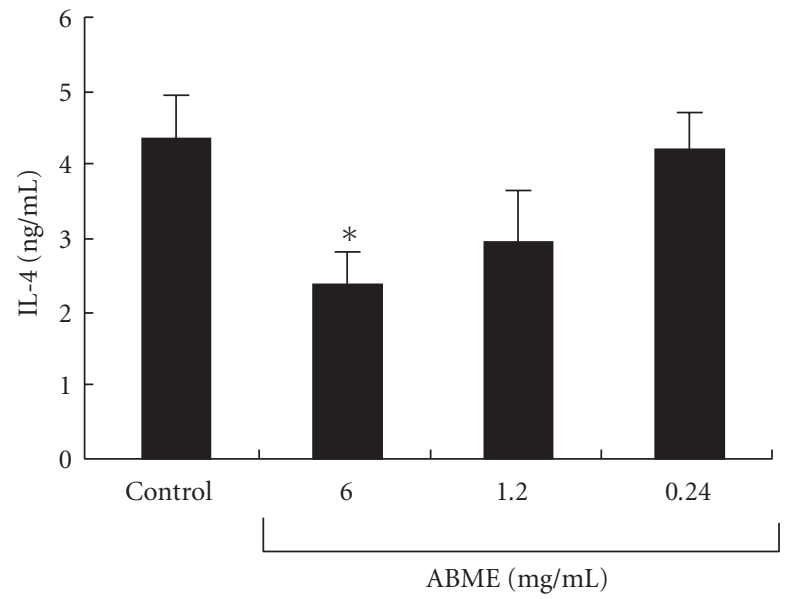

(a)

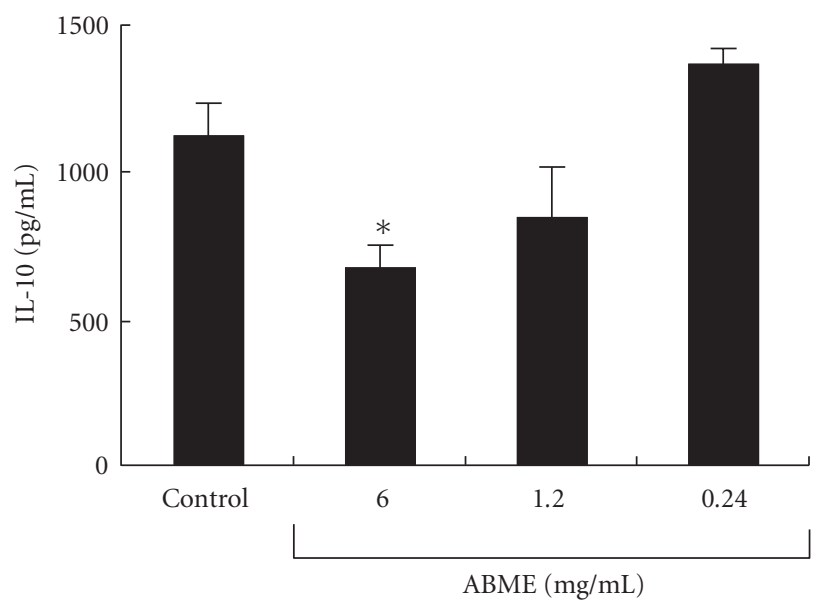

(c)

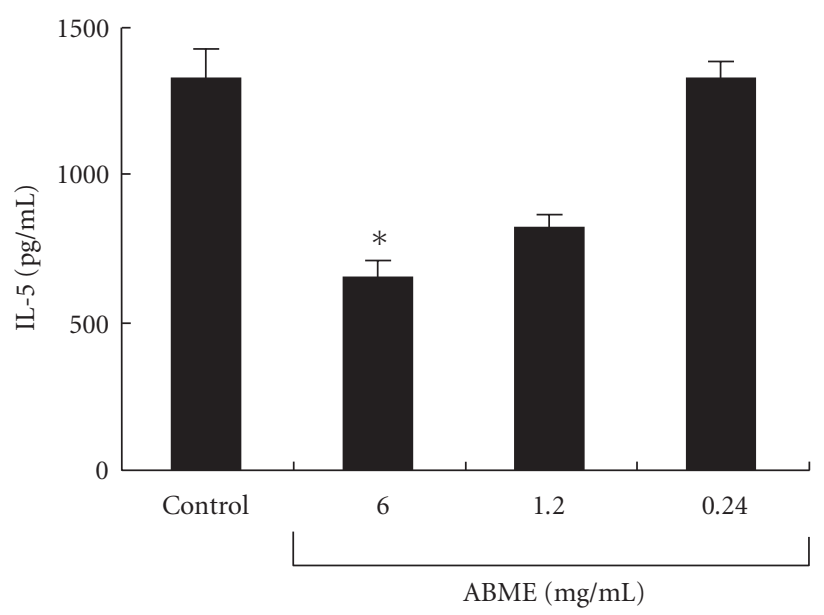

(b)

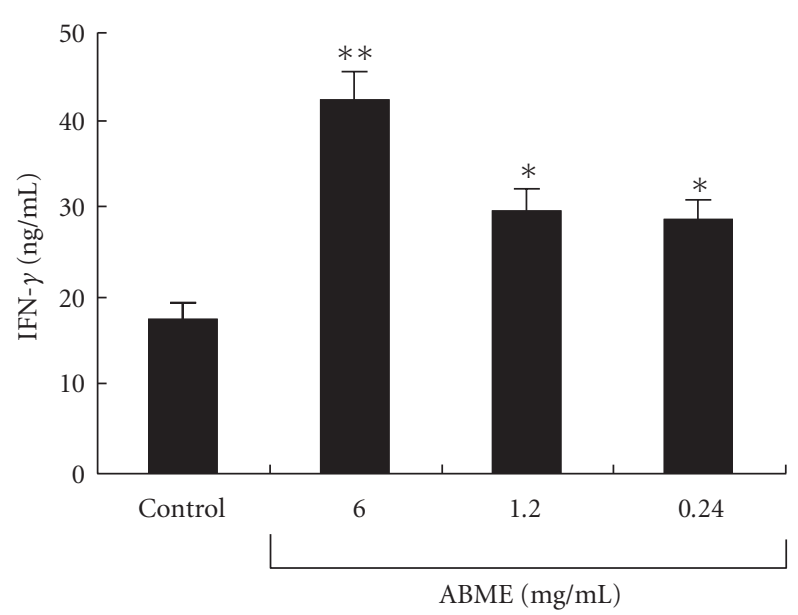

(d)

FIGURE 5: Effect of ABME on the cytokine profile of anti-CD3e/CD28 antibody-stimulated splenocytes in OVA-sensitized mice. Spleen cells from the mice of each group were stimulated with $5 \mu \mathrm{g} / \mathrm{ml}$ each of anti-CD $3 \varepsilon / 28$ antibody at $37^{\circ} \mathrm{C}$ for $48 \mathrm{~h}$. After incubation, the IL-4 (a), IL-5 (b), IL-10 (c), and IFN- $\gamma$ (d) in the culture medium were determined using a cytometric bead array immunoassay. Values represent the means \pm S.E. of 5 mice in each group. ${ }^{*} P<.05,{ }^{* *} P<.01$, significantly different from the values of the control group.

\section{Discussion}

A. blazei Murill is considered to be one of the most important edible and medicinal mushrooms in Japan. It was traditionally used for the treatment of many common diseases like atherosclerosis, hepatitis, hyperlipidemia, diabetes, dermatitis, cancer, and allergy disease [15]. Choi et al. [26] demonstrated that the water extract of the A. blazei Murill fruiting body suppressed allergic edema after oral administration and reduced histamine release by direct incubation with mast cells. In general, recent studies are focusing on elucidation action mechanisms for mushrooms extracts, including ABME, hence this study on the mechanism for the antiallergic effects exhibited after oral administration of ABME in vivo and in vitro systems.
The PCA reaction is a simple method for assessing the inhibitory effects of orally administered compounds on type I allergy. Many beneficial foods and components such as tea leave saponins [36] and mushrooms $[10,37]$ have been demonstrated antiallergic effects using this method. In this study, ABME suppressed PiCl-induced edema in a dosedependent manner (Figure 2). Moreover, ABME exerted a significant suppressive effect on the serum IgE levels of OVAsensitized mice at concentrations of $1.2 \mathrm{mg} / \mathrm{ml}$ and above (Figure 3). Similarly, Segawa et al. [29] demonstrated that oral administration of heat-killed Lactobacillus brevis inhibited total IgE production by improving the Th1/Th2 balance by enhancing IL- 12 and IFN- $\gamma$ production and inhibiting IL-4 production from OVA-sensitized mice splenocytes. It was demonstrated that the levels of IL-4 and IL-5 secreted 


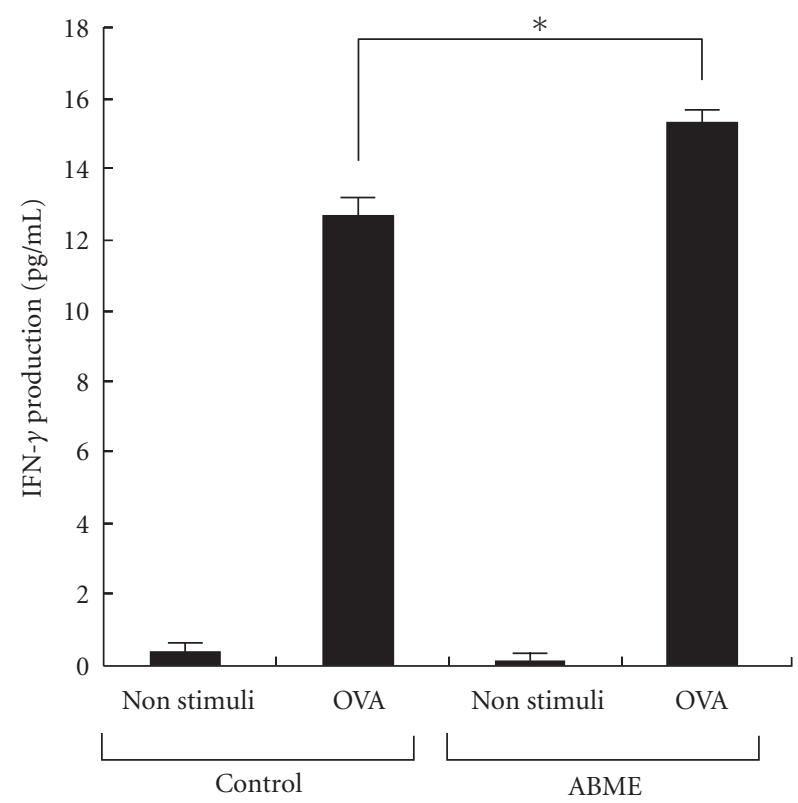

(a)

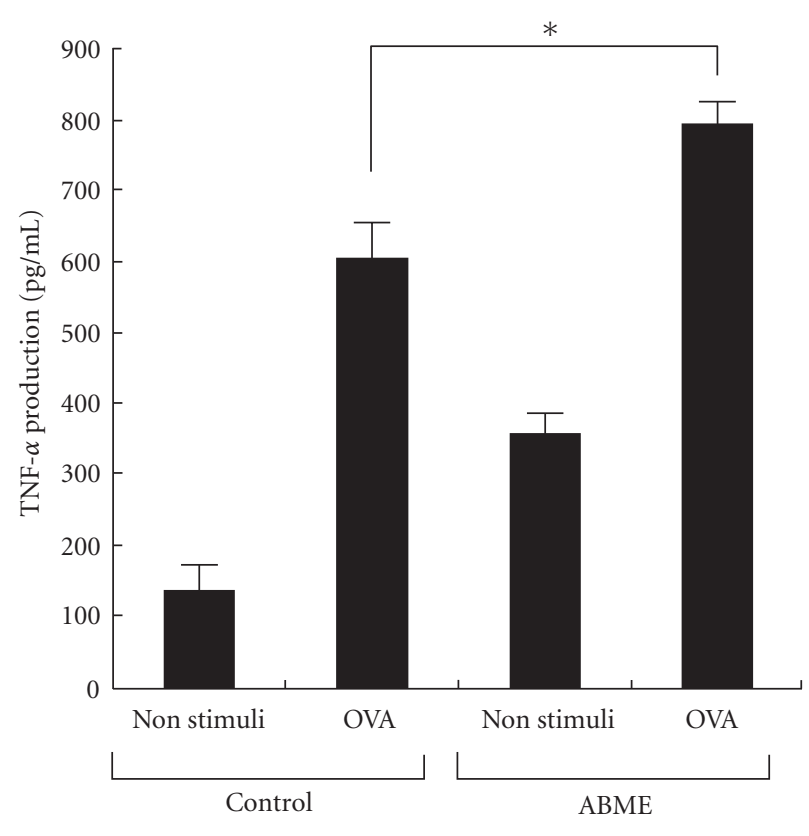

(b)

FIGURE 6: Effect of ABME on INF- $\gamma$ and TNF- $\alpha$ production from OVA-stimulated splenocytes prepared from OT-II mice via Caco-2 cells using a coculture system. Splenocytes were cultured in 24 -wells plates for $2 \mathrm{~h}$ in $5 \% \mathrm{CO}_{2}$ and incubated at $37^{\circ} \mathrm{C}$ to precipitate cells on the bottom of the plates. Then, the transwell inserts on which the Caco- 2 cells had been cultured were placed into the 24 well plates, which had been preloaded with splenocytes. Two hundred microliters of ABME $(250 \mu \mathrm{g} / \mathrm{ml})$ were applied to the apical side and incubated for $3 \mathrm{~h}$.

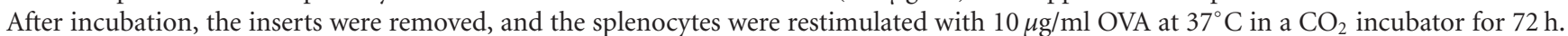
After incubation, the culture media were collected for the measurement of IFN- $\gamma$ (a) and TNF- $\alpha$ (b) contents as described in Materials and Methods. Values represent the means \pm SE. $(n=3) .{ }^{*} P<.05$, significantly different from the values of the control group.

from splenocytes restimulated with OVA in the 6.0 and $1.2 \mathrm{mg} / \mathrm{ml}$ ABME groups were lower than those in the control groups (Figure 4). Furthermore, restimulation with anti-CD3e/CD28 antibodies diminished IL-10 secretion but increased IFN- $\gamma$ production in addition to decreases of IL-4 and IL-5 production (Figure 5). Consequently, these results suggested that the oral administration of ABME shifted the Th1/Th2 balance towards Th1 and downregulated $\operatorname{IgE}$ levels. It was reported that ABME enhanced IL-12 and IL18 mRNA expression in macrophages [38]. Therefore, ABME may affect APC to modulate the Th1/Th2 balance.

It has been found that the gut immune cells are shifted to the Th2 type in allergic patients [24]. As various immune cells are affected by IEC in the gut [39], we used a coculture system using splenocytes from OT-II mice, which possess $\mathrm{CD}^{+} \mathrm{T}$ cells that highly express the OVA-specific TCR, and Caco-2 cells for assessing the effects of ABME on the differentiation of $\mathrm{T}$ cells via IEC. IFN- $\gamma$ and TNF$\alpha$ production was significantly increased in the ABMEand OVA-stimulated coculture system as compared to that without ABME treatment (Figure 6). IFN- $\gamma$ is secreted from Th1 cells and promotes the proliferation of Th1 cells [40]. TNF- $\alpha$ is one of the major cytokines secreted from activated APC [41-43]. Considering these results, our hypothesis is that ABME activates APC by interacting with IEC and then induces Th1 differentiation of naïve $\mathrm{T}$ cells in splenocytes by increasing the expression of Th1 cytokines and decreasing that of Th2 cytokines. This is the first report to show the effects of ABME via IEC. To confirm this hypothesis in which ABME activates APC through IEC, we examined whether ABME could activate macrophages in a slightly modified coculture system constructed of Caco-2 and RAW264.7 cells [44]. ABME enhanced TNF- $\alpha$ production from RAW264.7 cells in the coculture system but did not induce it during direct treatment of RAW264.7 cells alone. Moreover, nitric oxide was not detected in coculture system, albeit direct treatment of ABME to RAW 264.7 produced it (Figure 7). Recently, Nakao et al. [45] reported that hydrogen peroxide $\left(\mathrm{H}_{2} \mathrm{O}_{2}\right)$ induced the production of TNF- $\alpha$ in RAW 264.7 cells and did not support nitric oxide production unlike LPS. These results may suggest that ABME may indirectly affect immune cells such as macrophages through IEC which is produces $\mathrm{H}_{2} \mathrm{O}_{2}$ as a second messenger. However, further investigations are necessary to clarify how ABME activates macrophages through IEC.

It was demonstrated that ABME suppressed IgE content in OVA-sensitized mice by shifting the Th1/Th2 balance to Th1 and that IEC are absolutely imperative for activating APC, which induce the differentiation of naïve $T$ cells to Th1 type cells. It has been reported that A. blazei Murill contain $\beta$-glucans including the FIII-2-b fraction $[6,12-14]$. We showed that TNF- $\alpha$ production from the basolateral side 


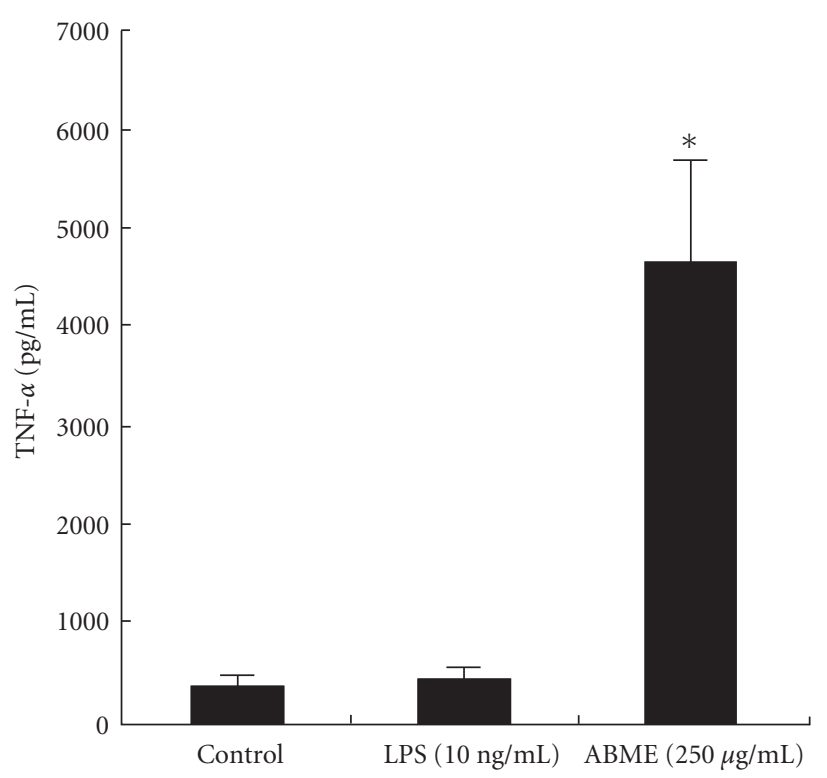

(a)

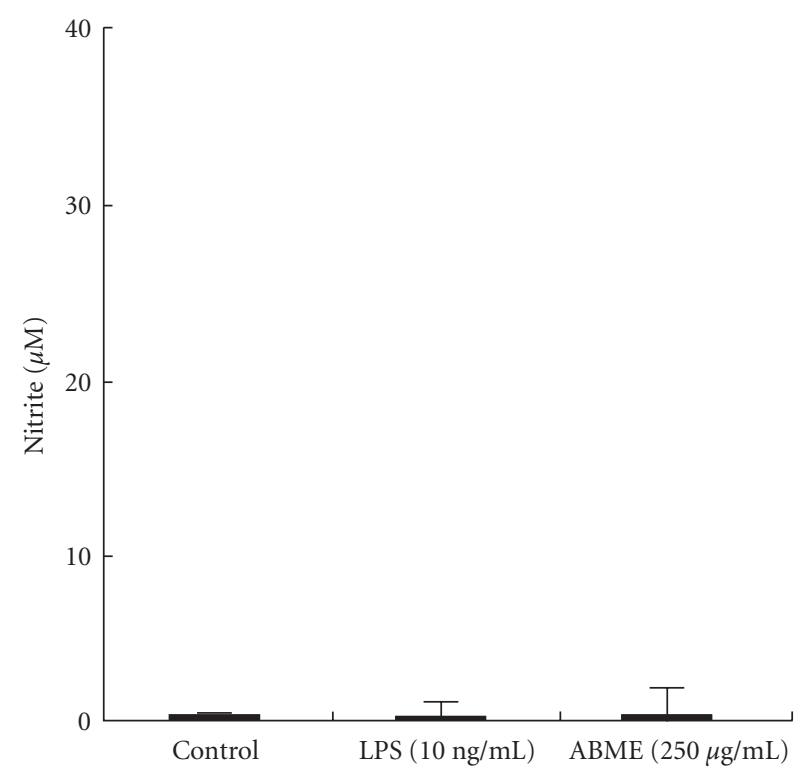

(c)

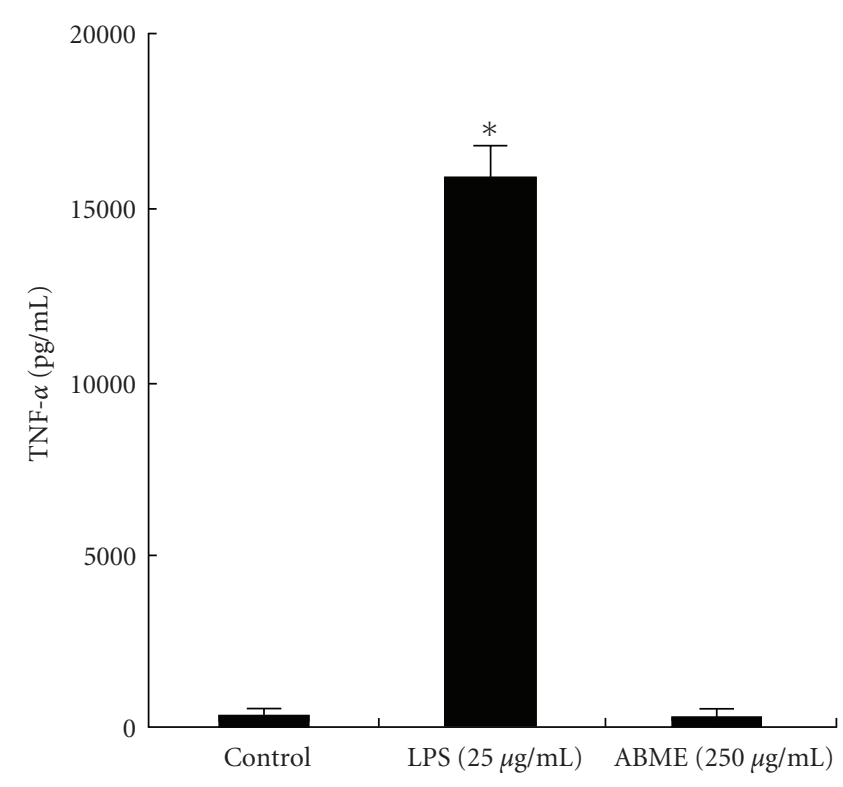

(b)

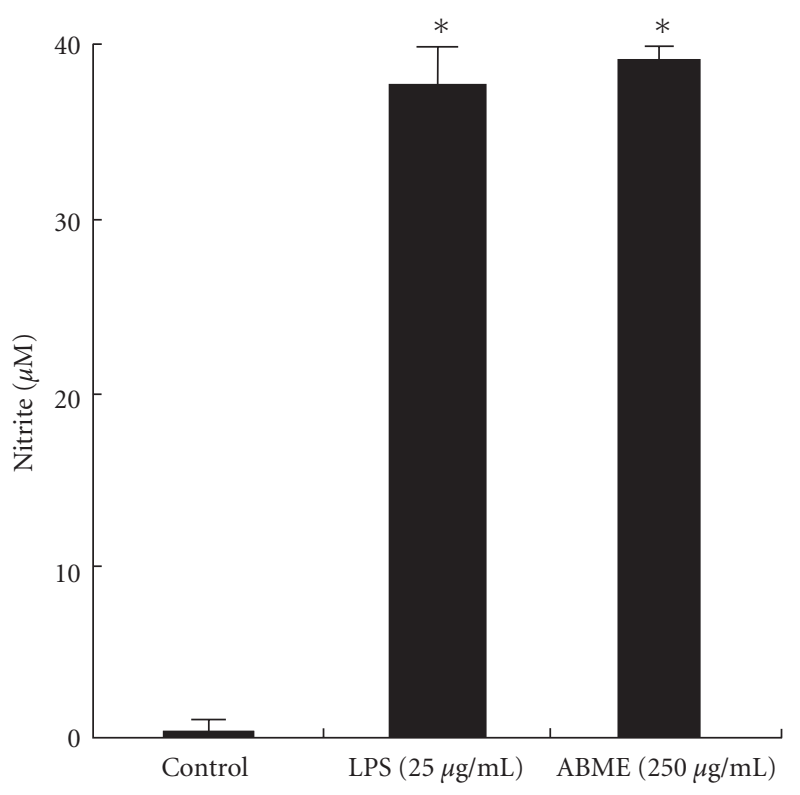

(d)

FIGURE 7: TNF- $\alpha$ and NO production in the coculture system or RAW264.7 cells alone treated with ABME or LPS ABME or LPS was added into the apical compartment of the Caco-2/RAW264.7 coculture system (a, c) or added directly into the RAW264.7 cells alone (b, d) and was then incubated for $12 \mathrm{~h}$. After incubation, the supernatants were collected. TNF- $\alpha$ and NO secretion into the culture supernatant (basolateral compartment) was determined by a cytotoxicity assay and Griess reagent. Values represent the means \pm SE. $(n=3)$. ${ }^{*} P<.05$, significantly different from the values of the control group.

of the coculture system was decreased to control levels when this antibody was pretreated with FIII-2-b or ABME solution (Figure 8). This result suggested that the active compound in ABME producing its antiallergic effect is FIII-2-b.
In conclusion, this paper demonstrates that FIII-2-b in ABME activates macrophages through IEC, but without them. These findings suggest that an activation process linked to macrophages is involved IEC. $\mathrm{H}_{2} \mathrm{O}_{2}$ which was 


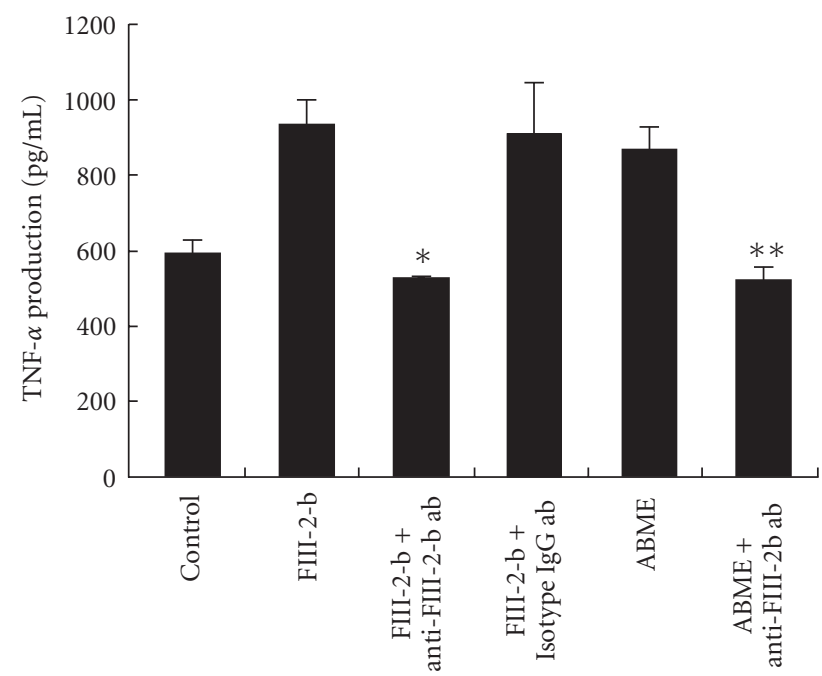

FIGURE 8: Effect of anti-FIII-2-b antibody on TNF- $\alpha$ production induced by ABME in a coculture system. Anti-FIII-2-b antibody or isotype IgG1 ( $25 \mathrm{ml} /$ well) were incubated with ABME for $2 \mathrm{~h}$ and centrifuged at 7000rpm for 5 minutes. The supernatant was added to the apical compartment of the Caco-2/RAW264.7 co-culture system for $3 \mathrm{~h}$. After the incubation, the supernatant from the basolateral side was collected, and TNF- $\alpha$ content was measured using a killing assay. Values represent the means \pm S.E. $(n=3) .{ }^{*} P<.05$ and ${ }^{* *} P<.05$, significantly different from the values for FIII-2-b and ABME treatment, respectively.
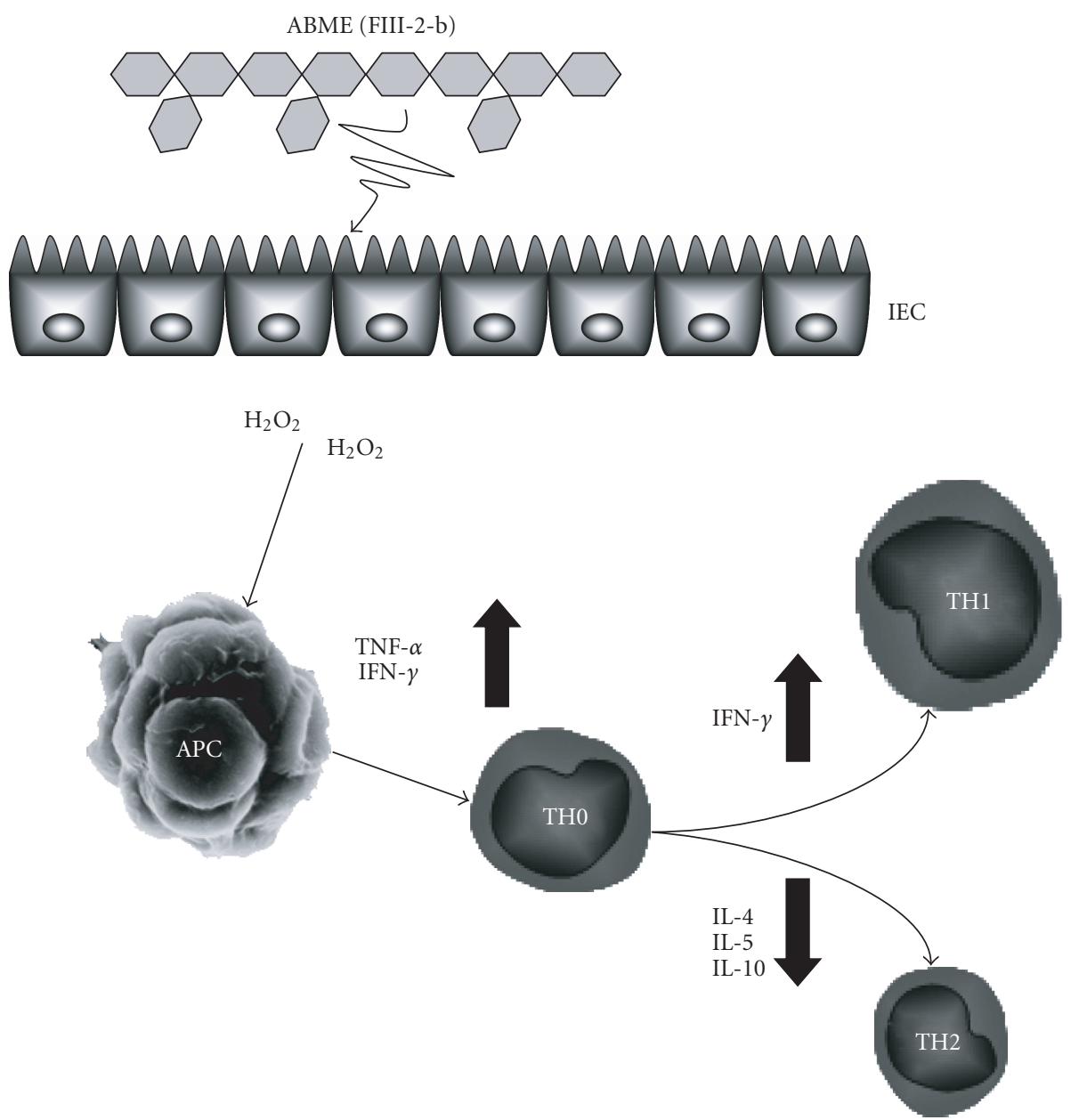

FIgure 9: Shift in Th1/Th2 balance to Th1 by ABME through intestinal epithelial cells. An intestinal epithelial cell is stimulated by FIII-2-b in ABME, which binds to a certain receptor. This stimulus produces second messengers, likely $\mathrm{H}_{2} \mathrm{O}_{2}$. Macrophages result in enhancement of TNF- $\alpha$ and IFN- $\gamma$ production. Produced INF- $\gamma$ affects Th1/Th2 balance which is important for allergy, and promotes the negative regulation of IL-4, 5, 10 which induce Th2 cell dominance, resulting in Th1 cell dominance in immune system. 
produced from Caco-2 plays an important role of a second messenger to produce TNF- $\alpha$ from macrophages and is involved in the signal transduction to promote the differentiation of naïve T cells into Th1 cells (Figure 9).

\section{Acknowledgments}

This paper was supported by Special Coordination Funds for Promoting Science and Technology, Creation of Innovation Centers for Advanced Interdisciplinary Research Areas (Innovative Bioproduction Kobe), MEXT, Japan. This paper was supported, in part, by the Iwade Mushroom Institute, Japan.

\section{References}

[1] J. W. Yunginger, “Anaphylaxis," Annals of Allergy, vol. 62, pp. 87-96, 1992.

[2] H. A. Sampson, "Update on food allergy," Journal of Allergy and Clinical Immunology, vol. 113, no. 5, pp. 805-819, 2004.

[3] M. I. Asher, M. Stephan, B. Bengt, K. W. L. Christopher, P. T. David, and K. W. Stephan, "Worldwide time trends in the prevalence of symptoms of asthma, allergic rhinoconjunctivitis, and eczema in childhood: ISAAC Phases One and Three repeat multicountry cross-sectional surveys," The Lancet, vol. 368, no. 9537, pp. 733-743, 2006.

[4] T. Ebina and Y. Fujimiya, "Antitumor effect of a peptideglucan preparation extracted from agaricus blazei in a doublegrafted tumor system in mice," Biotherapy, vol. 11, no. 4, pp. 259-265, 1998.

[5] H. Ito, K. Shimura, H. Itoh, and M. Kawade, "Antitumor effects of a new polysaccharide-protein complex (ATOM) prepared from Agaricus blazei (Iwade strain 101) "Himematsutake" and its mechanisms in tumor-bearing mice," Anticancer Research, vol. 17, pp. 277-284, 1997.

[6] T. Mizuno, R. Inagaki, T. Kanao, et al., "Antitumor activity and some properties of water-insoluble hetero-glycans from "Himematsutake," the fruiting body of Agaricus blazeiMurill " Agricultural Biology and Chemistry, vol. 54, pp. 2897-2905, 1990.

[7] P. R. Taylor, G. D. Brown, D. M. Reid et al., "The $\beta$-glucan receptor, dectin-1, is predominantly expressed on the surface of cells of the monocyte/macrophage and neutrophil lineages," Journal of Immunology, vol. 169, no. 7, pp. 3876-3882, 2002.

[8] S. Hossain, M. Hashimoto, E. K. Choudhury et al., "Dietary mushroom (Pleurotus ostreatus) ameliorates atherogenic lipid in hypercholesterolaemic rats," Clinical and Experimental Pharmacology and Physiology, vol. 30, no. 7, pp. 470-475, 2003.

[9] Y. Liu, Y. Fukuwatari, K. Okumura et al., "Immunomodulating activity of Agaricus brasiliensis KA21 in mice and in human volunteers," Evidence-Based Complementary and Alternative Medicine, vol. 5, no. 2, pp. 205-219, 2008.

[10] Y. H. Choi, G. H. Yan, O. H. Chai et al., "Inhibition of anaphylaxis-like reaction and mast cell activation by water extract from the fruiting body of Phellinus linteus," Biological and Pharmaceutical Bulletin, vol. 29, no. 7, pp. 1360-1365, 2006.

[11] U. Lindequist, T. H. J. Niedermeyer, and W.-D. Jülich, "The pharmacological potential of mushrooms," Evidence-based Complementary and Alternative Medicine, vol. 2, no. 3, pp. 285-299, 2005.
[12] H. Kawagishi, R. Inagaki, T. Kanao et al., "Fractionation and antitumor activity of the water-in-soluble residue of Agaricus blazei fruiting bodies," Carbohydrate Research, vol. 186, no. 2, pp. 267-273, 1989.

[13] H. Itoh, H. Ito, H. Amano, and H. Noda, "Inhibitory action of a (1->6)- $\beta$-D-glucan-protein complex (F III-2-b) isolated from Agaricus blazei Murill ("Himematsutake") on Meth A fibrosarcoma-bearing mice and its antitumor mechanism," Japanese Journal of Pharmacology, vol. 66, no. 2, pp. 265-271, 1994.

[14] Y. Fujimiya, Y. Suzuki, K.-I. Oshiman et al., "Selective tumoricidal effect of soluble proteoglucan extracted from the basidiomycete, Agaricus blazei Murill, mediated via natural killer cell activation and apoptosis," Cancer Immunology Immunotherapy, vol. 46, no. 3, pp. 147-159, 1998.

[15] F. Firenzuoli, L. Gori, and G. Lombardo, "The medicinal mushroom Agaricus blazei murrill: review of literature and pharmaco-toxicological problems," Evidence-Based Complementary and Alternative Medicine, vol. 5, no. 1, pp. 3-15, 2008.

[16] T. R. Mosmann, H. Cherwinski, M. W. Bond, M. A. Giedlin, and R. L. Coffman, "Two types of murine helper T cell clone. I. Definition according to profiles of lymphokine activities and secreted proteins. 1986," Journal of Immunology, vol. 136, pp. 2348-2357, 1989.

[17] B.-G. Moon, S. Takaki, K. Miyake, and K. Takatsu, “The role of IL-5 for Mature B-1 cells in homeostatic proliferation, cell survival, and Ig production," Journal of Immunology, vol. 172, no. 10, pp. 6020-6029, 2004.

[18] M. L. Kapsenberg, E. A. Wierenga, J. D. Bos, and H. M. Jansen, "Functional subsets of allergen-reactive human CD4 ${ }^{+} \mathrm{T}$ cells," Immunology Today, vol. 12, no. 11, pp. 392-395, 1991.

[19] J. A. Bellanti, "Cytokines and allergic diseases: clinical aspects," Allergy and Asthma Proceedings, vol. 19, pp. 337-341, 1998.

[20] L. Lu and W. A. Walker, "Pathologic and physiologic interactions of bacteria with the gastrointestinal epithelium," American Journal of Clinical Nutrition, vol. 73, no. 6, pp. 1124S-1130S, 2001.

[21] D. Jankovic, Z. Liu, and W. C. Gause, "Th1- and Th2cell commitment during infectious disease: asymmetry in divergent pathways," Trends in Immunology, vol. 22, no. 8, pp. 450-457, 2001.

[22] S. H. Lee, P. M. Starkey, and S. Gordon, "Quantitative analysis of total macrophage content in adult mouse tissues. Immunochemical studies with monoclonal antibody F4/80," Journal of Experimental Medicine, vol. 161, no. 3, pp. 475-489, 1985.

[23] L. Amati, M. Pepe, M. E. Passeri, M. L. Mastronardi, E. Jirillo, and V. Covelli, "Toll-like receptor signaling mechanisms involved in dendritic cell activation: potential therapeutic control of T cell polarization," Current Pharmaceutical Design, vol. 12, no. 32, pp. 4247-4254, 2006.

[24] A. B. Blázquez and M. C. Berin, "Gastrointestinal dendritic cells promote Th2 skewing via OX40L," Journal of Immunology, vol. 180, no. 7, pp. 4441-4450, 2008.

[25] N. Ohno, M. Furukawa, N. N. Miura, Y. Adachi, M. Motoi, and T. Yadomae, "Antitumor $\beta$-glucan from the cultured fruit body of Agaricus blazei," Biological and Pharmaceutical Bulletin, vol. 24, no. 7, pp. 820-828, 2001.

[26] Y. H. Choi, G. H. Yan, O. H. Chai et al., "Inhibitory effects of Agaricus blazei on mast cell-mediated anaphylaxis-like reactions," Biological and Pharmaceutical Bulletin, vol. 29, no. 7, pp. 1366-1371, 2006. 
[27] M. J. Barnden, J. Allison, W. R. Heath, and F. R. Carbone, "Defective TCR expression in transgenic mice constructed using cDNA- based $\alpha$ - and $\beta$-chain genes under the control of heterologous regulatory elements," Immunology and Cell Biology, vol. 76, no. 1, pp. 34-40, 1998.

[28] J. M. Robertson, P. E. Jensen, and B. D. Evavold, "DO11.10 and OT-II T cells recognize a C-terminal ovalbumin 323-339 epitope," Journal of Immunology, vol. 164, no. 9, pp. 4706$4712,2000$.

[29] S. Segawa, Y. Nakakita, Y. Takata et al., "Effect of oral administration of heat-killed Lactobacillus brevis SBC8803 on total and ovalbumin-specific immunoglobulin E production through the improvement of Th1/Th2 balance," International Journal of Food Microbiology, vol. 121, no. 1, pp. 1-10, 2008.

[30] K. Takada, N. Ohno, and T. Yadomae, "Binding of lysozyme to lipopolysaccharide suppresses tumor necrosis factor production in vivo," Infection and Immunity, vol. 62, no. 4, pp. 11711175, 1994.

[31] C. L. Green, A. D. Wagner, J. Glogowski, L. P. Skipper, S. J. Wishnok, and R. S. Tannebaum, "Analysis of nitrate, nitrite and $\left[{ }^{15} \mathrm{~N}\right]$ nitrate in biological fluids," Infection and Immunity, vol. 62, no. 4, pp. 1171-1175, 1994.

[32] M. Mizono, K.-I. Minato, and H. Tsuchida, "Preparation and specificity of antibodies to an anti-tumor $\beta$-glucan, lentinan," Biochemistry and Molecular Biology International, vol. 39, no. 4, pp. 679-685, 1996.

[33] D. Cantrell, "T cell antigen receptor signal transduction pathways," Annual Review of Immunology, vol. 14, pp. 259274, 1996.

[34] L. P. Kane, J. Lin, and A. Weiss, "Signal transduction by the TCR for antigen," Current Opinion in Immunology, vol. 12, no. 3, pp. 242-249, 2000.

[35] B. M. Carreno and M. Collins, "The B7 family of ligands and its receptors: new pathways for costimulation and inhibition of immune responses," Annual Review of Immunology, vol. 20, pp. 29-53, 2002.

[36] M. Akagi, "Anti-allergic effect of tea-leaf saponin (TLS) from tea leaves (Camellia sinensis var. sinensis)," Biological and Pharmaceutical Bulletin, vol. 20, no. 5, pp. 565-567, 1997.

[37] N. Inagaki, T. Shibata, T. Itoh et al., "Inhibition of IgEdependent mouse triphasic cutaneous reaction by a boiling water fraction separated from mycelium of Phellinus linteus," Evidence-Based Complementary and Alternative Medicine, vol. 2, no. 3, pp. 369-374, 2005.

[38] M. Mizuno, S. Kawakami, Y. Sakamoto, and N. Fujitake, "Macrophages stimulated by polysaccharide purified from Agaricus brasiliensis S. Wasser et al. (Agaricomycetideae) enhance mRNA expression of Th1 cytokine including IL-12 and 18," International Journal of Medicinal Mushrooms, vol. 5, pp. 397-403, 2003.

[39] D. Artis, "Epithelial-cell recognition of commensal bacteria and maintenance of immune homeostasis in the gut," Nature Reviews Immunology, vol. 8, no. 6, pp. 411-420, 2008.

[40] R. Howea, S. Dillona, L. Rogersa, et al., "Evidence for dendritic cell-dependent CD4(+) T helper-1 type responses to commensal bacteria in normal human intestinal lamina propria," Clinical Immunology, vol. 131, pp. 317-332, 2009.

[41] R. Keller, R. Keist, A. Wechsler, T. P. Leist, and P. H. van der Meide, "Mechanisms of macrophage-mediated tumor cell killing: a comparative analysis of the roles of reactive nitrogen intermediates and tumor necrosis factor," International Journal of Cancer, vol. 46, no. 4, pp. 682-686, 1990.
[42] K. Sorimachi, K. Akimoto, Y. Ikehara, K. Inafuku, A. Okubo, and S. Yamazaki, "Secretion of TNF- $\alpha$, IL- 8 and nitric oxide by macrophages activated with Agaricus blazei Murill fractions in vitro," Cell Structure and Function, vol. 26, no. 2, pp. 103-108, 2001.

[43] C.-H. Shu, B.-J. Wen, and K.-J. Lin, "Monitoring the polysaccharide quality of Agaricus blazei in submerged culture by examining molecular weight distribution and TNF- $\alpha$ release capability of macrophage cell line RAW 264.7," Biotechnology Letters, vol. 25, pp. 2061-2064, 2003.

[44] T. Tanoue, Y. Nishitani, K. Kanazawa, T. Hashimoto, and M. Mizuno, "In vitro model to estimate gut inflammation using co-cultured Caco-2 and RAW264.7 cells," Biochemical and Biophysical Research Communications, vol. 374, no. 3, pp. 565$569,2008$.

[45] N. Nakao, T. Kurokawa, T. Nonami, G. Tumurkhuu, N. Koide, and T. Yokochi, "Hydrogen peroxide induces the production of tumor necrosis factor- $\alpha$ in RAW 264.7 macrophage cells via activation of p38 and stress-activated protein kinase," Innate Immunity, vol. 14, no. 3, pp. 190-196, 2008. 


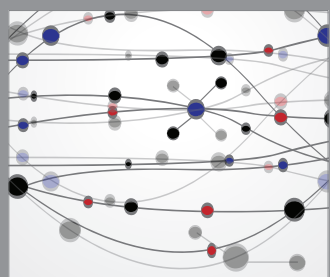

The Scientific World Journal
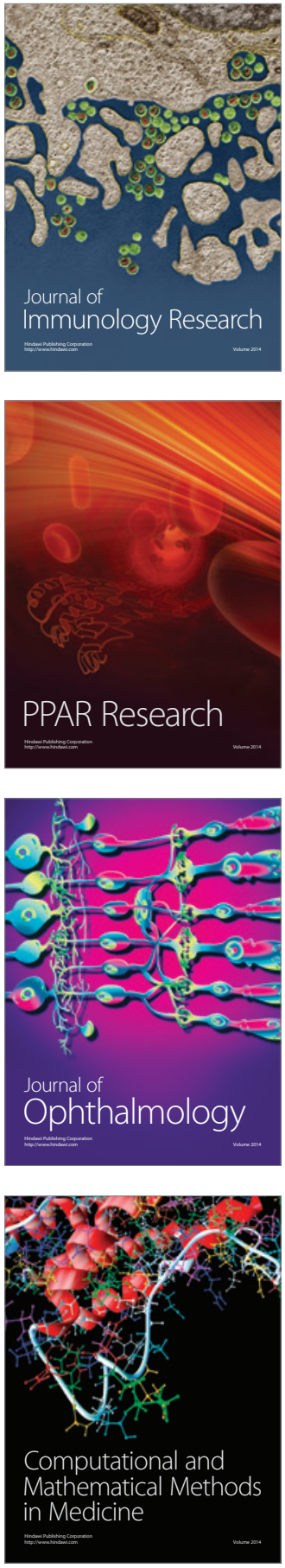

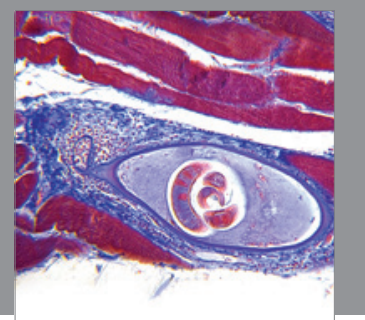

Gastroenterology

Research and Practice
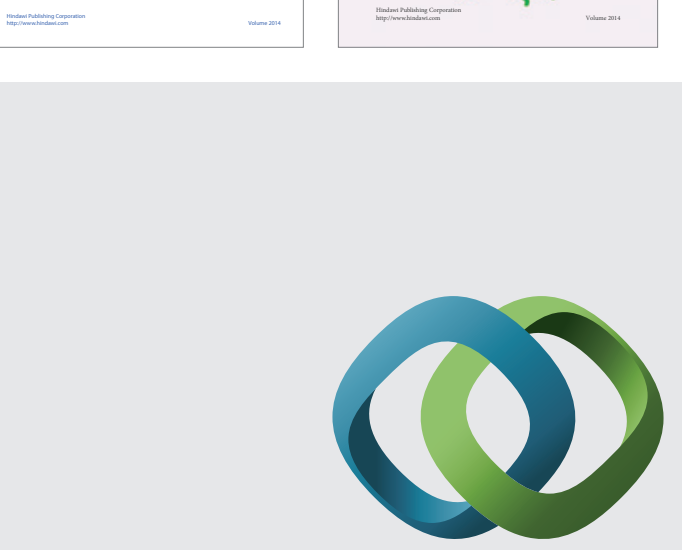

\section{Hindawi}

Submit your manuscripts at

http://www.hindawi.com
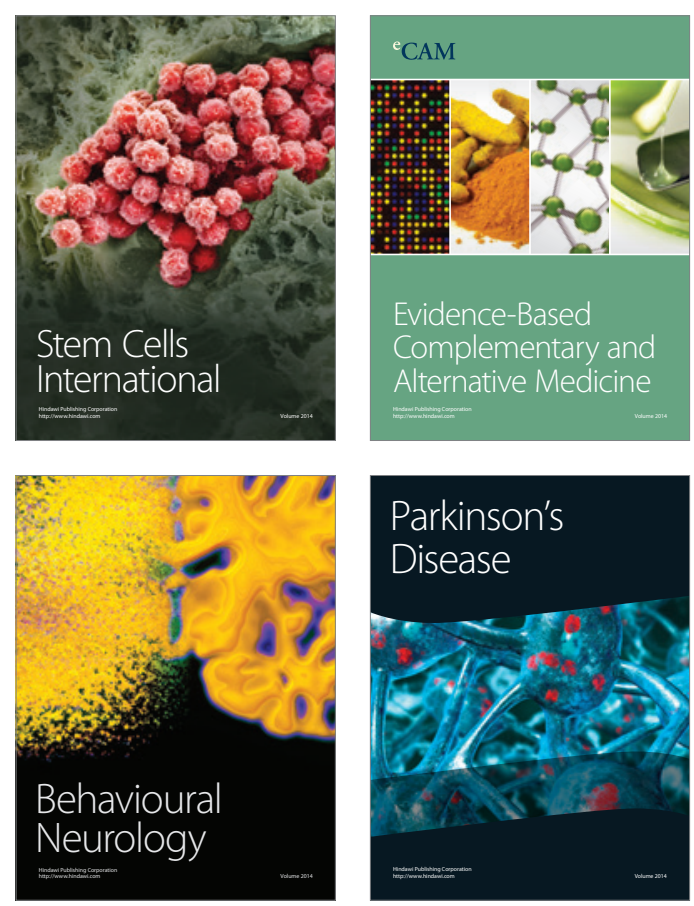

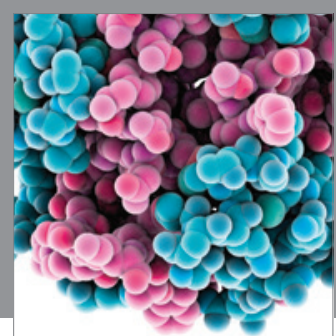

Journal of
Diabetes Research

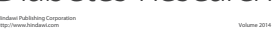

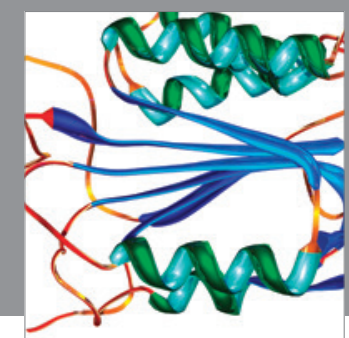

Disease Markers
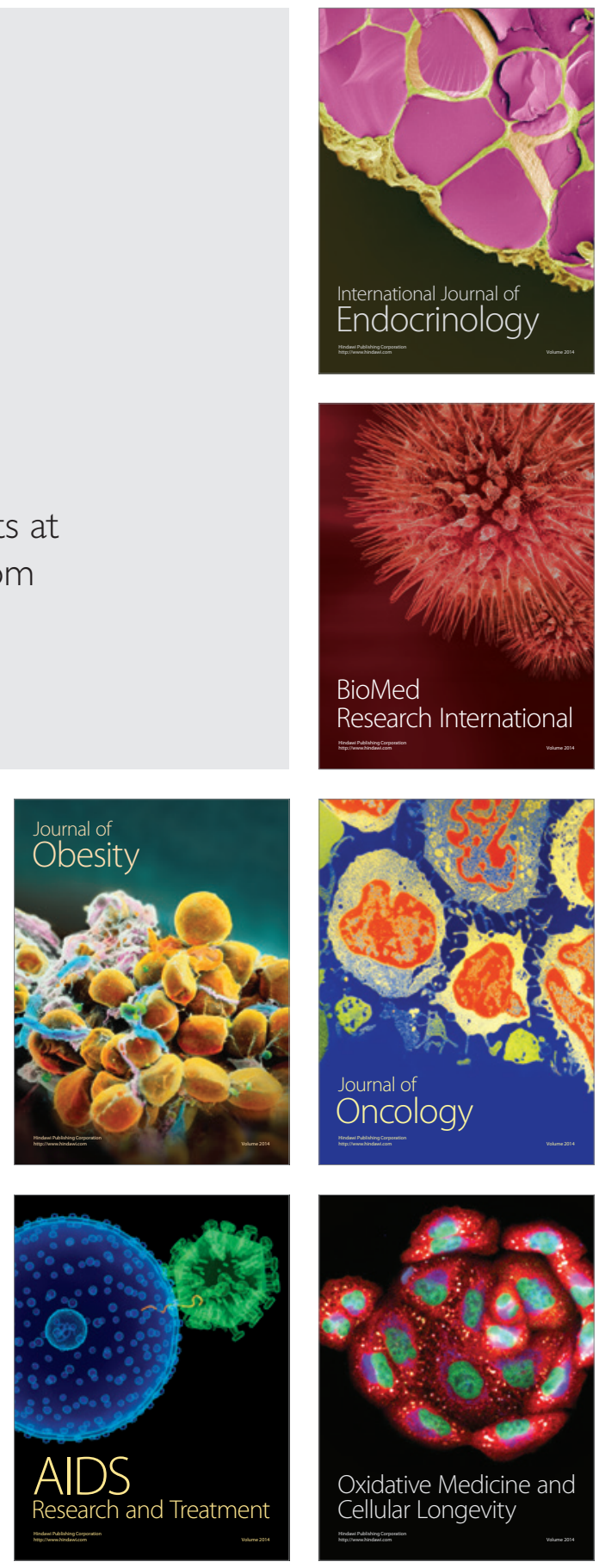